\title{
FUNGICIDAL CONTROL OF EARLY AND LATE BLIGHT OF THE POTATO IN PUERTO RICO
}

\author{
L. A. Alvarez-García, J. Adsuar, J. P. Rodriguez, A. C. Miret, F. Arostegui, \\ R. Olivencia, and $F$. Rochet ${ }^{1}$
}

\section{INTRODUCTION}

The control of early and late blight of potato is one of the important problems in the commercial production of potatoes in Puerto Rico. The diseases considerably reduce the yield and greatly affect the market value of the product.

Early and late blight of potatoes are endemic diseases in Puerto Rico and epiphytotics may occur at any time during the growing season from November to February. The weather at this time of the year is rather variable with occasional cool nights and warm days, frequent rains, and high relative humidity. Late blight is usually more serious in this environment.

It is generally known that late blight is a low-temperature disease. The temperature during the winter season fluctuates from $70^{\circ}$ to $75^{\circ} \mathrm{F}$. during daytime and from $60^{\circ}$ to $65^{\circ} \mathrm{F}$. at night. These conditions are favorable for development of late blight. Rainfall is not so important as long as there are cool nights and sufficient dew for swamspore germination and leaf penetration. Early blight is a hot humid-weather disease and temperatures above $70^{\circ} \mathrm{F}$. favor its development. Such weather conditions occur in Puerto Rico during the potato-growing season.

Late blight of potatoes is considered a seedborne disease. In certain regions the seed piece is the source of the primary inoculum. Under our conditions the source of the primary inoculum does not necessarily depend on infected tubers, if we consider that tomato, eggplant, and other solanaceous plants grow spontaneously the year round.

The occurrence of epiphytotics of early and late blight in Puerto Rico therefore is primarily due to the endemism of the pathogens responsible for these diseases and to the generally favorable local environment. Puerto Rico is a small island, but there are many unsuspected microclimates, both in the lowlands and in the highlands, apparently adequate for the yearround existence of these micro-organisms.

The question of controlling early and late blight is of deep concern to the farmers and the public. Early and late blight have been kept under fairly

${ }^{1}$ Plant Pathologist and Head of Department, Plant Pathologist, Associate Agronomist, Research Assistant in Agronomy, Associate Agronomist, Assistant Plant Breeder, and Assistant Agronomist, respectively, Agricultural Experiment Station, University of Puerto Rico, Río Piedras, P. R. 
less soluble than Bordeaux Mixture, therefore less phytotoxic, and can be applied with less risk during the early growth of the seedlings. Bordeaux and Fermate are a little toxic under hot, humid conditions but not to the extreme of killing the plants.

A field test with seedlings taken from each respective treatment showed that the early phytotoxic effect of Bordeaux Mixture and Fermate had very little or no effect on the yield of leaf tobacco.

\section{SUMMARY}

1. Experiments for the comparative testing of new fungicidal chemicals for the control of damping-off of tobacco were performed at Aibonito, Caguas, and San Lorenzo.

2. In Aibonito, Bordeaux Mixture and Copper A Compound proved superior to Fermate, Dithane Z-78, and Parzate.

3. In San Lorenzo, Bordeaux Mixture and Copper A Compound also proved superior to Fermate, Dithane Z-78, and Parzate.

4. In Caguas, Bordeaux Mixture and Copper A Compound again proved superior to Dithane Z-78 and to Fermate.

5. All treatments, however, were practically effective in controlling damping-off.

\section{RESUMEN}

Con el propósito de comparar la eficacia de varios nuevos fungicidas con el caldo bordelés, para combatir la micosis del pie (sancocho) en los semilleros de tabaco, se realizaron varios experimentos en Aibonito, San Lorenzo y Caguas. El resultado de la experimentación ha demostrado que todos los fungicidas probados son prácticamente eficaces y dominan el "sancocho" de los semilleros de tabaco.

No obstante, los mejores resultados, en términos generales, fueron los conseguidos con los compuestos de cobre. 
good control by the use of the classical Bordeaux Mixture. The synthesis and discovery of new fungicidal chemicals has opened a new field of control measures. There are reports of effective control of early and late blight with some of these new chemicals. The order of merit of some of those chemicals, however, varies with the crops and the environment under which they are tested. Hence, it has been necessary to determine the efficacy of some of them in our local environment. This paper deals with the results obtained with some new fungicides (compared with the standard Bordeaux Mixture) in controlling early and late blight of potato.

\section{MATERIALS AND METHODS}

Unless otherwise stated, all the potatoes planted have been grown from certified seed tubers brought from the mainland. The seed were planted

TABLE 1.-Active principles of fungicidal chemicals tested for their effect on potato yields in the experiments reported

\begin{tabular}{|c|c|c|}
\hline No. & Trade name & Active principle \\
\hline 1 & Bordeaux Mixture & Basic copper sulfates \\
\hline 2 & Copper A Compound & Copper oxychloride \\
\hline 3 & Dithane D-14 & Disodium ethylene bisdithiocarbamate \\
\hline 4 & Dithane Z-78 & Zinc ethylene bisdithiocarbamate \\
\hline 5 & Parzate & Do. \\
\hline 6 & Phygon XL & Dichloronaphtoquinone \\
\hline 7 & Fermate & Ferric dimethyl dithiocarbamate \\
\hline 8 & Zerlate & Zinc dimethyl dithiocarbamate \\
\hline
\end{tabular}

immediately after breaking dormancy. Previous to planting each was cut in pieces and sown 3 feet apart, in ridges, 15 inches in the row. The potatoes were grown without irrigation.

The fungicidal chemicals used in our tests (table 1) were in great majority solids insoluble in water. They entered readily into suspension because of the addition of wettable agents. In all instances the recommendations of the manufacturers were followed. The chemicals were sprayed the same day and immediately after being prepared. A Vermorell-type sprayer was used to apply the chemicals on both the upper and under surfaces of the leaves. Weekly sprayings were performed. Records of rainfall, relative humidity, and temperatures were taken whenever possible. Samples of leaves were examined every week to establish the degree of infection and the responsible organism.

Treated plants were grown in plots, in replicate, to permit statistical analysis. Records were taken of the appearance of the treated plants, injury of the leaves, type of growth, and yield and quality of produce. The plants 
were sprayed with concentrated $\mathrm{CuSO}_{4}$ solution before harvesting in order to kill the mycelia and spores of the pathogen in the soil and in the aerial parts of the plants. In this manner the possibility of contamination of the potato tubers at harvesting was eliminated.

To evaluate the fungicidal effects of the chemicals tested, the data were statistically analyzed.

\section{EXPERIMENTAL RESULTS}

\section{Control of Early Blight}

FIELD TRIAL NO. 1

A first trial was conducted at the Río Piedras Agricultural Experiment Station, in field A-1. This time the varieties Red Bliss Triumph and Irish Cobbler were grown. The seed were sown December 29, 1948. The plantation was fertilized with a 10-10-5 fertilizer, at a rate of 1,200 pounds per acre. The fungicides tested were Parzate, Zerlate, Dithane Z-78, Copper A Compound, and Bordeaux Mixture. The treatments were randomized and replicated nine times in plots of $1 / 200$ of an acre. During this late planting, the weather was unfavorable for development of early blight. The temperature was around $27^{\circ} \mathrm{C}$. and there was a dry spell, but there was sufficient water of condensation during the night to permit spore germination and penetration. Irrigation water was used whenever necessary to permit good growth of the plants. The merit of each treatment is shown in table 2.

\section{FIELD TRIAL NO. 2}

A second trial with Red Bliss Triumph potato was conducted at Cidra. A 10-10-5 fertilizer was applied at the rate of 1,500 pounds per acre. The seed were sown February 2, 1949, and the potatoes were harvested May 12, 1949. They were grown in randomized plots of $1 / 100$ of an acre. The treatments were replicated six times following a paired-plot system. The fungicides tested were Parzate, Zerlate, Phygon XL, Dithane Z-78, Copper A Compound, and Bordeaux Mixture. The experiment was carried on in a field on the T. Fernández Farm, Bo. Bayamón, Cidra. Rainfall during the growing season was approximately 7 inches. Watering was sometimes necessary.

The plants were sprayed with the chemicals following the method indicated previously. During the growing period the potatoes suffered a mild attack of Alternaria blight. The results of this experiment are shown in table 3.

FIELD TRIAL NO. 3

Another trial was conducted with Red Bliss Triumph potato at the Corozal Substation. The seed were sown in February 1950 and the crop was 
TABLE 2.-Results of fungicidal treatments to control early blight (Alternaria solani) in the varieties Red Bliss Triumph and Irish Cobbler potatoes during the planting season Dec. 29-Apr. 8,1949

[Field trial No. 1]

\begin{tabular}{|c|c|c|}
\hline \multirow{2}{*}{ Fungicide used } & \multicolumn{2}{|c|}{ Mean yield of potatoes per acre for- } \\
\hline & Red Bliss Triumph ${ }^{1}$ & Irish Cobbler ${ }^{2}$ \\
\hline & Cwt. & Cwot. \\
\hline Zerlate. & 42.60 & 59.60 \\
\hline Copper A Compound...$\ldots \ldots \ldots \ldots$ & 41.20 & 50.60 \\
\hline Dithane Z-78 $\ldots \ldots \ldots \ldots \ldots \ldots \ldots$ & 39.60 & 58.60 \\
\hline 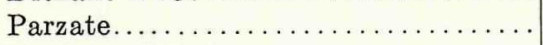 & 38.20 & 55.80 \\
\hline Bordeaux Mixture................ & 35.40 & 44.00 \\
\hline Check............. & 37.40 & 57.80 \\
\hline
\end{tabular}

${ }^{1} \mathrm{~L} . \mathrm{S} . \mathrm{D}$. at the 5 -percent level $=3.860$; at the 1 -percent level $=5.165$. Zerlate was superior at the 5-percent level when compared with Parzate, Copper A Compound, Bordeaux Mixture, and Check. At the 1-percent level Zerlate proved better than Copper A Compound, Bordeaux Mixture, and Check.

${ }^{2} \mathrm{~L}$. S. D, at the 5-percent level $=4.709$; at the 1 -percent level $=6.300$. Zerlate, Dithane Z-78, Parzate, and Copper A Compound were significantly superior at the 1-percent level when compared with Bordeaux Mixture, but not when compared with the Check. Zerlate proved better than Parzate at the 5-percent level and better than Copper A Compound and Bordeaux Mixture at the 1-percent level.

TABLE 3.-Results of fungicidal treatments to control early blight (Alternaria solani) in the Red Bliss Triumph potato grown at Cidra during the planting season Feb. 2-May 12, 1949

[Field trial No. 2]

\begin{tabular}{|c|c|c|c|}
\hline \multirow{2}{*}{ Fungicide used } & \multicolumn{3}{|c|}{ Mean yield of potatoes per acre, by size } \\
\hline & Large $^{1}$ & Small2 & Large and small ${ }^{3}$ \\
\hline & Cwt. & Cwt. & Cwt. \\
\hline Parzate. & 71.80 & 17.0 & 88.50 \\
\hline Zerlate... & 79.70 & 14.8 & 94.50 \\
\hline Phygon XL ..... & 67.30 & 14.3 & 81.20 \\
\hline Dithane Z-78. & 71.70 & 14.2 & 90.50 \\
\hline Copper A Compound ............... & 68.20 & 13.8 & 81.50 \\
\hline Bordeaux Mixture .............. & 68.20 & 15.5 & 81.50 \\
\hline Check ...................... & 60.5 & 15.3 & 75.70 \\
\hline
\end{tabular}

${ }^{1} \mathrm{~L} . \mathrm{S} . \mathrm{D}$. at the 5 -percent level $=10.50$; at the 1 -percent level $=14.14$.

${ }^{2}$ For plants yielding large potatoes Parzate, Zerlate, Phygon XL, Dithane Z-78, and Copper A Compound were better than the Check at the 5-percent level; Zerlate was better than Phygon XL or Bordeaux Mixture at the 5-percent level, and than the Check at the 1-percent level.

${ }^{3}$ For plants yielding large and small potatoes together Zerlate was better than Phygon XL or Bordeaux Mixture at the 5-percent level and better than the Check at the 1-percent level, while Parzate and Dithane Z-78 were better than the Check at the 5-percent level. The fungicides rated in the following order of merit: Zerlate, Dithane Z-78, and Parzate. 
harvested on May 12, 1950. The potato seed used were kept in cool storage $\left(50-60^{\circ} \mathrm{F}\right.$.) to planting time.

The period was dry and the potatoes were watered twice during the growing season. The plants were seriously attacked with early blight, caused by Alternaria solani. Insects were controlled with DDT and nicotine sulfate.

The potatoes harvested were classified into large and small. The results are shown in table 4.

TABLE 4.-Results of fungicidal treatments to control early blight (Alternaria solani) in the Red Bliss Triumph potato grown at the Corozal Substation during the planting season February 8-May 12, 1950

[Field trial No. 3]

\begin{tabular}{|c|c|c|}
\hline \multirow{2}{*}{ Fungicide used } & \multicolumn{2}{|c|}{ Mean yield of potatoes per acre, by size } \\
\hline & Large and small ${ }^{1}$ & Large $^{2}$ \\
\hline & Cwt. & Cwt. \\
\hline Check (No DDT or nicotine sulfate).. & 34.83 & 23.17 \\
\hline Parzate...................... & 51.33 & 38.67 \\
\hline 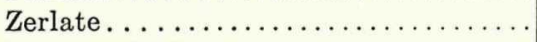 & 47.35 & 35.67 \\
\hline Dithane Z-78 ......... & 49.50 & 36.17 \\
\hline Phygon XL........ & 40.33 & 29.19 \\
\hline Bordeaux Mixture... & 46.00 & 33.17 \\
\hline Check (DDT plus nicotine sulfate).... & 38.66 & 28.33 \\
\hline
\end{tabular}

${ }^{1} \mathrm{~L}$. S. D. at the 5 -percent level $=3.06$; at the 1 -percent level $=4.13$. Parzate proved better than the Check without, and the Check with DDT plus nicotine, Phygon XL, and Bordeaux Mixture at the 1-percent level. Dithane Z-78 was better than the Check with DDT plus nicotine, and Phygon XL at the 1-percent level, and than Bordeaux Mixture at the 5-percent level.

${ }^{2} \mathrm{~L}$. S. D. at the 5-percent level $=2.57$; at the 1 -percent level $=3.35$. Parzate proved superior at the 1-percent level to Zerlate, Phygon XL, Bordeaux Mixture, and the Check without DDT plus nicotine. Dithane Z-78 proved better than Phygon XL, and both Checks at the 1-percent level, and than Bordeaux Mixture at the 5-percent level.

Early blight (Alternaria solani) was prevalent during the growing season. The results were different from those obtained in the previous year when Zerlate was the best fungicide and Dithane Z-78 second. This year Parzate was the best fungicide and Dithane Z-78 second best for early blight control. Although the result was not statistically significant, Zerlate was very nearly as good as Parzate.

\section{Control of Late Blight}

FIELD TRIAL NO. 4

A fourth experiment was conducted at Stubb's Farm, Bo. Bayamón, Cidra, with the potato variety Katahdin. The field was fertilized with 1,500 
pounds of a 10-10-5 fertilizer, applied before planting. The planting was made January 24, 1945. The potatoes were harvested on May 25 and 26, 1945. Bordeaux Mixture and Dithane D-14 were compared. The statistical analysis of the results is shown in table 5 .

FIELD TRIAL NO. 5

A fifth experiment was conducted at the Corozal Substation. Red Bliss Triumph potatoes were sown in September 1950, and the crop was harvested during December 1950. Early during the growing season the temperature was around $80^{\circ} \mathrm{F}$. Light scattered rainfall occurred at the beginning of the growing season. However, abundant fainfall, approximately 16 inches, was concurrent with the appearance of early blight. During the middle of the

TABLE 5.-Results of fungicidal treatments to contiol late blight (Phytophthora infestants) of Katahdin potatoes grown at Cidra in the planting season Jan. 24-May 25, 1945

[Field trial No. 4]

\begin{tabular}{|c|c|}
\hline Fungicide used & Mean yield of potatoes per acre \\
\hline $\begin{array}{l} \\
\text { Dithane D-14 } \ldots \ldots \ldots \ldots \ldots \ldots \ldots \ldots \ldots \\
\text { Bordeaux Mixture } \ldots \ldots \ldots \ldots \ldots \ldots \ldots \ldots \\
\text { Check } \ldots \ldots \ldots \ldots \ldots\end{array}$ & $\begin{array}{l}\text { Cwt. } \\
47.92 \\
48.27 \\
41.10\end{array}$ \\
\hline
\end{tabular}

${ }^{1}$ L. S. D. at the 5 -percent level $=2.75$; at the 1 -percent level $=3.64$. No significant differences between Dithane D-14, and Bordeaux Mixture. Dithane D-14, and Bordeaux Mixture were better than the Check at the 1-percent level.

growing season the temperature dropped to $70^{\circ} \mathrm{F}$. and the relative humidity was high. It thus favored the development of late blight. The plants were grown in plots of $1 / 108.9$ of an acre, the treatments were replicated 5 times, and the number of plants per plot was 200. An incomplete block system was used consisting of 16 treatments of 4 groups of 4 plots in each plot. The fungicides tested were Bordeaux Mixture, Copper A Compound, Zerlate, Dithane Z-78, Parzate, and Phygon. The results of these treatments are shown in table 6 .

\section{FIELD TRIAL NO. 6}

The same method of planting and spraying used for the previous experiments was followed in Field Trial No. 6. The planting was to have been made simultaneously with the same variety used in Trial No. 4, but because it proved impossible to obtain fresh seed from the mainland at that time, it had to be postponed until January 1951, when the field in Corozal was sown with Red Bliss Triumph potatoes. The crop was harvested on March 
TABLE 6.-Results of fungicidal treatments to control late blight (Phytophthora infestans) in Red Bliss Triumph potatoes grown at the Corozal Substation during the planting season Sept. 9-January 1950

[Field Trial No. 5]

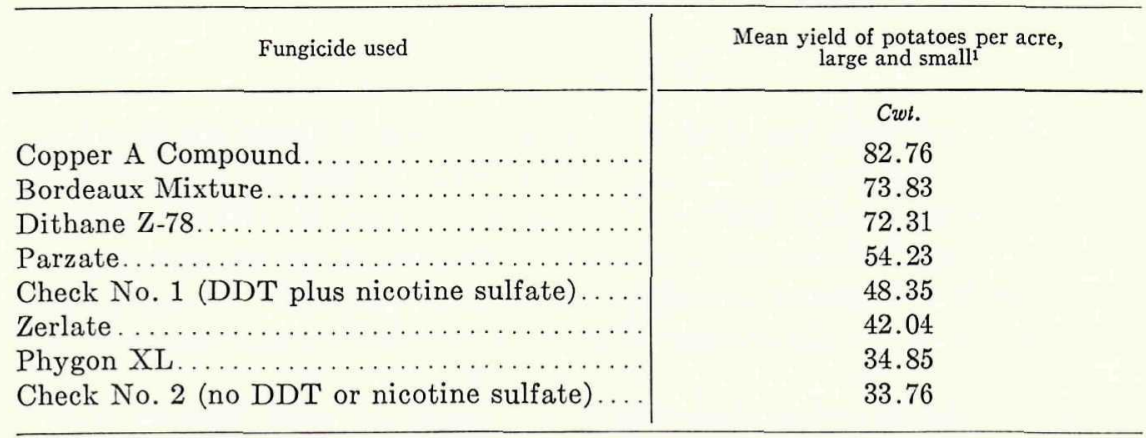

${ }^{1} \mathrm{~L}$. S. D. at the 1 -percent level $=22.05$; at the 5 -percent level $=16.7$. Copper $\mathrm{A}$ Compound, Bordeaux Mixture, and Dithane Z-78 proved better than Parzate, Zerlate, Phygon XL, and the two Checks at the 1-percent level. At the 5-percent level, Parzate proved better than Phygon XL, and Check No. 1.

TABLE 7.-Results of fungicidal treatments to control late blight (Phytophthora infestans) of Red Bliss Triumph potatoes grown at the Corozal Substation during the planting season January-March 1951

[Field Trial No.6]

\begin{tabular}{|c|c|c|}
\hline \multirow{2}{*}{ Fungicide used } & \multicolumn{2}{|c|}{ Mean yield of potatoes per acre, by size } \\
\hline & Large $^{1}$ & Large and small ${ }^{2}$ \\
\hline & Cwt. & Cwt. \\
\hline Bordeaux Mixture. . & 45.13 & 67.36 \\
\hline Copper A Compound. & 42.51 & 62.57 \\
\hline Phygon XL . . . . . . . . . . . . . & 38.80 & 60.39 \\
\hline 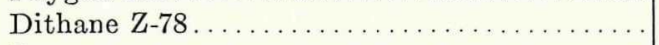 & 37.06 & 57.99 \\
\hline 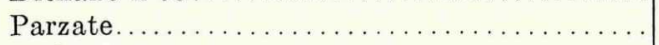 & 34.23 & 55.59 \\
\hline Zerlate....... & 32.70 & 50.14 \\
\hline Check No. 1, (DDT plus nicotine sulfate). & 26.16 & 47.31 \\
\hline Check No. 2, (no DDT or nicotine sulfate).... & 23.32 & 46.87 \\
\hline
\end{tabular}

1 There was no significant difference at the 1-percent level among the chemical treatments and all these treatments were superior to the Check with no insecticides. At the 5-percent level all these chemical treatments were better than both Checks.

${ }^{2} \mathrm{~L}$. S. D. at the 1 -percent level $=21.11$; at the 5 -percent level $=15.64$. There was no significant difference among the treatments at the 1-percent level. At the 5-percent level, Bordeaux Mixture, Copper A Compound, Phygon XL, Dithane Z-78, and Parzate were superior to Zerlate, and both the Checks. 
19, 1951. Phygon-treated plants looked yellowish but had only a low degree of infection.

It can be seen in table 7 that the yield was less than that obtained previously. However, during this period a dry spell lowered the yield. Though the yield was less, the potatoes were larger, better shaped, and of better quality. No decay has been observed so far. Results are shown in table 7.

\section{CONCLUSIONS}

Results of tests made with new fungicides at Río Piedras, Cidra, and Corozal have shown that these chemicals can control early and late blight of potatoes.

The efficacy of the fungicides varied with the environmental conditions and also with the type of blight. The use of chemical treatments substantially increased the yield of potatoes per acre.

During very adverse seasons when rainfall was scanty or too abundant, the yield was rather low, even though the plants were sprayed. Spraying increased production during so-called normal years.

Potato culture - on a limited scale-would be less risky if potato varieties with at least 1-gene resistance to the common race of $P$. infestans are grown. Better results are to be expected in the future when new 3gene-resistant varieties, with good adaptation to short-day periods of growth are released.

\section{SUMMARY}

Experiments were conducted at Río Piedras, Cidra, and Corozal to determine the relative efficacy of certain newer fungicides for control of early and late blight of potatoes.

The data derived from the various experiments may be summarized as follows for early blight control:

1. At Río Piedras, December-April 1949, Zerlate was superior at the 5-percent level to Parzate, Copper A Compound, and Bordeaux Mixture for the control of early blight. At the 1-percent level, Zerlate proved better than Copper A Compound or Bordeaux Mixture.

2. At Cidra, February-May 1949, Zerlate was better than Phygon XL or Bordeaux Mixture at the 5-percent level for control of early blight. Parzate and Dithane Z-78 were better than the Check at the 5-percent level.

3. At Corozal, February-May 1949, Parzate proved superior to Zerlate, Phygon XL, Bordeaux Mixture, and the Check at the 1-percent level. Dithane Z-78 was better than Phygon XL and both Checks at the 
1-percent level, and superior to Bordeaux Mixture at the 5-percent level.

For late blight control:

1. At Cidra, January-May 1945, Dithane D-14 was equal to Bordeaux Mixture and superior to the Check for the control of late blight.

2. At Corozal, September-December 1950, Copper A Compound, Bordeaux Mixture, and Dithane Z-78 proved superior to Parzate, Zerlate, Phygon XL, and the Check at the 1-percent level. At the 5-percent level Parzate proved better than Phygon XL and Check No. 1.

3. At Corozal, January-March 1951, a second experiment showed that Copper A Compound, Bordeaux Mixture, Dithane Z-78, Parzate, Phygon XL, and Zerlate were equally superior to the Check at the 1-percent level. At the 5-percent level Bordeaux Mixture, Copper A Compound, Phygon XL, Dithane Z-78, and Parzate were superior to Zerlate and to the Checks.

\section{RESUMEN}

En este trabajo se presentan datos en relación con la eficacia de los nuevos fungicidas para combatir el tizón tempranero (Alternaria solani) y el tizón tardío (Phytophthora infestans) respectivamente, que atacan a las papas (Solanum tuberosum) en Puerto Rico.

Los resultados de los experimentos para combatir el tizón tempranero fueron:

1. En Río Piedras, durante el período de cultivo de la variedad Red Bliss, desde diciembre 29 a abril 8, 1949, el Zerlato en términos estadísticos del 5 por ciento $^{2}$ fué superior al Parzato, al Compuesto A de cobre, al Caldo Bordelés y al testigo. $\mathrm{Y}$ al 1 por ciento, el Zerlato fué superior al Compuesto A de cobre, al Caldo Bordelés y al testigo.

En las papas de la variedad Irish Cobbler, el Zerlato, el Ditano Z-78, el Parzato y el Compuesto A de cobre fueron superiores al Caldo Bordelés al 1 por ciento, pero no así cuando se compararon con el testigo. El Zerlato, al 5 por ciento, fué superior al Parzato, y al 1 por ciento, también superior al Compuesto A de cobre y al Caldo Bordelés.

2. En Cidra, durante el período de cultivo, desde febrero a mayo de 1949, cuando se usó la variedad Red Bliss Triumph, el Zerlato fué superior al Phygon XL, y al Caldo Bordelés al 5 por ciento y mejor que el testigo, al 1 por ciento. El Ditano Z-78 y el Parzato fueron superiores al testigo, al 5 por ciento.

3. En Corozal, con la variedad Red Bliss Triumph, durante el período de febrero 8 a mayo 12 del 1950, el Parzato fué superior al Zerlato, al

${ }^{2}$ Cuando se mencionan el 1 y el 5 por ciento éstos se refieren a los por cientos estadísticos, según el análisis estadístico de Fisher. 
Phygon XL, al Caldo Bordelés y al testigo, sin insecticidas, al 1 por ciento. Al 1 por ciento, el Ditano Z-78, fué superior al Phygon XL y también superior a los dos testigos y al Caldo Bordelés, al 5 por ciento.

En Cuanto al tizón tardío:

1. En Cidra, durante el período de cultivo de enero 24 a mayo 25, 1945, con la variedad Katahdin, el Dithano Z-78 y el Caldo Bordelés fueron igualmente superiores al testigo, al 1 por ciento.

2. En Corozal, de septiembre a diciembre del 1950, el Compuesto A de cobre, el Caldo Bordelés y el Ditano Z-78 fueron superiores al Parzato, al Phygon XL y a los dos testigos, al 1 por ciento. Al 5 por ciento, el Parzato fué superior al Phygon XL y al testigo número 1.

3. En Corozal, de enero a marzo 19 del 1951, los fungicidas: Caldo Bordelés, Compuesto A de Cobre, Phygon XL, Ditano Z-78, Parzato y Zerlato no demostraron ser superiores a los testigos; porque la enfermedad no tuvo importancia. Al 5 por ciento, se notó que hubo una pequeña superioridad del Caldo Bordelés, el Compuesto A de cobre, el Phygon XL, el Ditano Z-78 y el Parzato sobre el Zerlato y los testigos 1 y 2.

\section{REFERENCES CONSULTED}

1. Black, William, Blight in relation to potato breeding, Ann. Appl. Biol. 34 631-3 1947.

2. Crosier, Willard, Studies on the biology of Phytophthora infestans (Mont.) de Bary, Cornell Agr. Expt. Sta. Memoir 155, 1934.

3. Jones, L. R., Giddings, N. J., and Lutman, B. F., Investigations of the potato fungus Phytophthora infestans, U. S. Dept. Agr. Bul. 245, 100pp., 1912. (Also published as Vt. Agr. Expt. Sta. Bul. 168).

4. Melhus, I. E., Hibernation of Phytophthora infestans in the Irish potato, J. Agr. Res. 5 71-102 1915.

5. - Germination and infection with the fungus of the late blight of potato (Phytophthora infestans), Wis. Agr. Expt. Sta. Res. Bul. 37, 64pp., 1915.

6. Mills, W. R., The National Potato-Breeding Program twentieth Annual Report to Cooperators, 153-4 pp., mimeographed U. S. Dept. Agr. 180pp., 1949.

7. Reddrick, Donald, and William Crosier, Biological specialization in Phytophthora infestans, Am. Pot. J. 10 129-34 1933.

8. - Development of blight-immune varieties, Amer. Pot. J. 20 118-26 1943.

9. U. S. Dept. Agr., the Plant Disease Reporter National-wide results with fungicides in 1947-51, Supplements 176, 181, 192, and 213, 1948-51. 